\title{
Segregation and Coactivation of Developing Neocortical Layer 1 Neurons
}

\author{
Takeshi Soda, ${ }^{1}$ Ryo Nakashima, ${ }^{2}$ Dai Watanabe, ${ }^{1}$ Kazunori Nakajima, ${ }^{3,4}$ Ira Pastan, ${ }^{5}$ and Shigetada Nakanishi ${ }^{1,2}$ \\ ${ }^{1}$ Department of Biological Sciences, Kyoto University Faculty of Medicine, and ${ }^{2}$ Department of Molecular and System Biology, Kyoto University Graduate \\ School of Biostudies, Kyoto 606-8501, Japan, ${ }^{3}$ Department of Anatomy, Keio University School of Medicine, Tokyo 160-8582, Japan, ${ }^{4}$ Department of \\ Molecular Neurobiology, Institute of DNA Medicine, Jikei University School of Medicine, Tokyo 105-8461, Japan, and ${ }^{5}$ Laboratory of Molecular Biology, \\ Center for Cancer Research, National Cancer Institute, National Institutes of Health, Bethesda, Maryland 20892
}

Layer 1 in the developing cerebral cortex is populated by two basic neuronal cell types, Cajal-Retzius (CR) cells and non-CR cells. We generated transgenic mice in which green fluorescent protein (GFP) was driven by the promoter of metabotropic glutamate receptor subtype 2 and expressed specifically in CR cells during cortical development. On the basis of the precise identification of CR cells with GFP fluorescence, we pursued developmental changes and synaptic mechanisms of both CR and non-CR cells during the postnatal period. Immunostaining in combination with GFP fluorescence imaging showed that GFP and reelin, a protein involved in corticogenesis, completely overlap in CR cells at postnatal day 0 . At the subsequent postnatal stage, reelin-positive neurons are segregated and categorized into GFP-positive/GABA-negative CR cells and GFP-negative/GABA-positive non-CR cells. Individual and simultaneous whole-cell recordings of CR and non-CR cells in developing cerebral slices revealed that spontaneous and electrically evoked postsynaptic currents (sPSCs and ePSCs) measured in CR and non-CR cells are differentially mediated by $\mathrm{GABA}_{\mathrm{A}}$ receptors versus $\mathrm{GABA}_{\mathrm{A}}$, AMPA, and NMDA receptors, respectively. Furthermore, CR and non-CR cells show synchronized repetitive barrages of sPSCs that reflect a network-driven activity in the developing cerebral cortex. These findings imply that the layer 1 neurons dynamically change and play a distinct and integral role in the postnatal developing neocortex.

Key words: Cajal-Retzius cell; transgenic mouse; green fluorescent protein; neocortex; layer 1; synaptic transmission; neural circuit; reelin

\begin{abstract}
Introduction
Layer 1 is the most distinct and characteristic lamina of the cerebral cortex. As the cortex develops, neuroblasts migrate and apical dendrites of developing pyramidal neurons make synaptic connections in layer 1 (Marín-Padilla, 1984, 1998). Layer 1 is populated by two basic neuronal cell types during development: CR and non-CR (Marín-Padilla, 1984, 1998). CR cells are neurons generated early in the developing cortex; they appear as a main cell population in layer 1 , and begin to disappear during the postnatal period (Marín-Padilla, 1984, 1998; Meyer et al., 1999). CR cells and their equivalents in hippocampus produce an extracellular matrix protein called reelin (D’Arcangelo et al., 1995; Ogawa et al., 1995). Reelin is defective in the reeler mouse mutant, which shows altered neuronal migration in neocortex, hippocampus, and cerebellum and an abnormal cortical layer formation (Caviness and Sidman, 1973; D'Arcangelo et al., 1995;
\end{abstract}

Received Jan. 23, 2003; revised May 8, 2003; accepted May 13, 2003.

This work was supported in part by research grants from the Ministry of Education, Science, and Culture of Japan and the International Resource Program of the National Cancer Institute. We thank Katsuhiko Mikoshiba for providing CR-50 antibody, Harunori Ohmori and Nobuaki Tamamaki for invaluable advice, and Kumlesh K. Dev for careful reading of this manuscript.

Correspondence should be addressed to Dr. Shigetada Nakanishi, Department of Biological Sciences, Kyoto University Faculty of Medicine, Yoshida, Sakyo-ku, Kyoto 606-8501, Japan. E-mail: snakanis@phy.med.kyotou.ac.jp.

Copyright $\odot 2003$ Society for Neuroscience $\quad 0270-6474 / 03 / 236272-08 \$ 15.00 / 0$
Ogawa et al., 1995). Thus, CR cells play a pivotal role in cortical development. Most non-CR cells are GABAergic, whereas CR cells are glutamate-immunoreactive but not GABAimmunoreactive (Huntley and Jones, 1990; Del Río et al., 1992, 1995; Fonseca et al., 1995). Recent calcium imaging analysis has shown that the developing layer 1 neurons exhibit correlated neuronal activity that could serve as the scaffold for the activitydependent development of intracortical connections (Schwartz et al., 1998; Aguiló et al., 1999). However, both the mechanism and the function of the network activity in layer 1 remain poorly understood.

It has been reported that metabotropic glutamate receptor subtype 2 (mGluR2) immunoreactivity is detectable in CR celllike bipolar neurons in layer 1 of the adult rat cerebral cortex (Ohishi et al., 1998). Because the fusion transgene of human interleukin-2 receptor and green fluorescent protein (hIL-2R/ GFP), when driven by the mGluR2 promoter, is selectively expressed in many mGluR2-expressing neurons (Watanabe et al., 1998), we examined the possible expression of the hIL-2R/GFP transgene in CR cells during the postnatal period. GFP fluorescence imaging combined with immunohistochemical analysis revealed a specific expression of hIL-2R/GFP in CR cells of the developing cerebral cortex. Thus, the identification of GFPpositive CR cells provided a unique opportunity to pursue synaptic mechanisms of the neural activity of developing layer 1 cells. 
In this investigation, we first report the characterization of developmental changes of CR and non-CR cells during the postnatal period. We then report analysis of whole-cell recordings of CR and non-CR cells, indicating that synaptic inputs to CR cells and non-CR cells are clearly segregated into GABAergic alone and GABAergic plus glutamatergic, respectively. Furthermore, CR cells and non-CR cells show synchronized, repetitive barrages of sPSCs that reflect a network-driven activity in the developing cortex. These findings demonstrate that the layer 1 neurons serve as an integral part of an early cortical network.

\section{Materials and Methods}

Immunohistochemistry, cell counting, and biocytin labeling. The IG17 line of homozygous transgenic mice from postnatal day 0 (P0) to P10 was used in all experiments, unless otherwise stated. All procedures were performed according to the guidelines of the Kyoto University Faculty of Medicine. Immunostaining of slice preparations $(40 \mu \mathrm{m})$ was performed as described previously (Ohishi et al., 1998). The primary antibodies used were mouse monoclonal antibodies against reelin (CR-50; 1:400) (Ogawa et al., 1995) and calretinin (1:5000; Chemicon, Temecula, CA) and rabbit polyclonal antibodies against calretinin (1:2500; Chemicon) and GABA (1:4000; Sigma, St. Louis, MO). The secondary antibodies used were cyanine 3 (Cy3)-conjugated goat IgG against mouse IgG or rabbit IgG (1:800) and Cy5-conjugated goat IgG against mouse IgG (1: 200) (Jackson ImmunoResearch, West Grove, PA). Images were captured with an inverted laser-scanning confocal microscope (LSM510; Zeiss, Jena, Germany) equipped with a water-immersion objective ( $40 \times$, 1.2 numerical aperture). Image stacks were collected at the $1.7-2.3 \mu \mathrm{m}$ $z$-axis step to cover the full depth of the slice. Cell counting was performed in coronal sections of three portions of the neocortex corresponding to $1.0 \mathrm{~mm}$ rostral, $1.7 \mathrm{~mm}$ caudal, and $3.3 \mathrm{~mm}$ caudal to the bregma in the adult brain; cell numbers were counted from the ectorhinal cortex to the retrosplenial agranular cortex in layer 1. Biocytin labeling was performed using whole-cell patch-clamp recording techniques (see below); cells were filled with an internal solution containing $1 \%$ biocytin. Slices were then fixed overnight in 3.7\% formaldehyde in PBS, and biocytin-labeled cells were visualized either with Alexa Fluor 594conjugated streptavidin (1:500; Molecular Probes, Eugene, OR) or with Alexa Fluor 546-conjugated streptavidin (1:500) in combination with immunostaining with the reelin antibody followed by Cy5-conjugated secondary antibody.

Electrophysiology. Whole-cell patch-clamp recordings of coronal cerebral slices (300-400 $\mu \mathrm{m}$ thick) were performed at room temperature as described previously (Watanabe et al., 1998). Slices were recorded on an upright fluorescence microscope (Zeiss Axioscop 2) equipped with a $63 \times$ water-immersion objective for sequential visualization of infrared differential interference contrast (IR-DIC) and GFP images. The extracellular solution contained the following (in mM): $125 \mathrm{NaCl}, 2.5 \mathrm{KCl}, 2$ $\mathrm{CaCl}_{2}, 1 \mathrm{MgCl}_{2}, 1.25 \mathrm{NaH}_{2} \mathrm{PO}_{4}, 26 \mathrm{NaHCO}_{3}$, and 25 glucose, $\mathrm{pH} 7.4$, then bubbled with $95 \% \mathrm{O}_{2}$ and $5 \% \mathrm{CO}_{2}$; in some experiments, $\mathrm{MgCl}_{2}$ was omitted. The patch pipette (3-5 M $\Omega$ ) was filled with a solution containing the following (in $\mathrm{mM}$ ): $120 \mathrm{CsCl}, 1 \mathrm{MgCl}_{2}, 10 \mathrm{HEPES}, 10$ BAPTA, 2 ATP, 0.4 GTP, 5 creatine phosphate (CP), $5 \mathrm{~N}$-(2,6dimethylphenylcarbamoylmethyl) triethylammonium bromide (QX314) and 5 tetraethylammonium (TEA), adjusted to $\mathrm{pH}$ 7.4. The reversal potential was measured in a $\mathrm{CsH}_{2} \mathrm{PO}_{4}$-based intracellular solution containing the following (in mM): $90 \mathrm{CsH}_{2} \mathrm{PO}_{4}, 10 \mathrm{CsCl}, 10 \mathrm{HEPES}$, 10 BAPTA, 2 Mg-ATP, 0.4 GTP, 5 CP, 5 QX314, and 5 TEA, adjusted to $\mathrm{pH}$ 7.4. In current-clamp experiments, the pipette solution contained the following (in mM): $150 \mathrm{KCl}, 10 \mathrm{NaCl}, 10$ HEPES, and $0.1 \mathrm{EGTA}$, adjusted to $\mathrm{pH}$ 7.4. Liquid junction potentials were determined as $-10 \mathrm{mV}$ and corrected for the $\mathrm{CsH}_{2} \mathrm{PO}_{4}$-based pipette solution. Synaptic responses were evoked by constant current stimulation $(100 \mu \mathrm{sec}, 50-200 \mu \mathrm{A})$ with a glass electrode filled with the extracellular solution. In paired recordings, synaptic coupling was tested by delivering a depolarizing current into the presumptive presynaptic cell. Antagonists were bathapplied with the following concentrations: (-)-bicuculline methochloride (bicuculline; $20 \mu \mathrm{M}$ ), D-(-)-2-amino-5-phosphonopentanoic acid
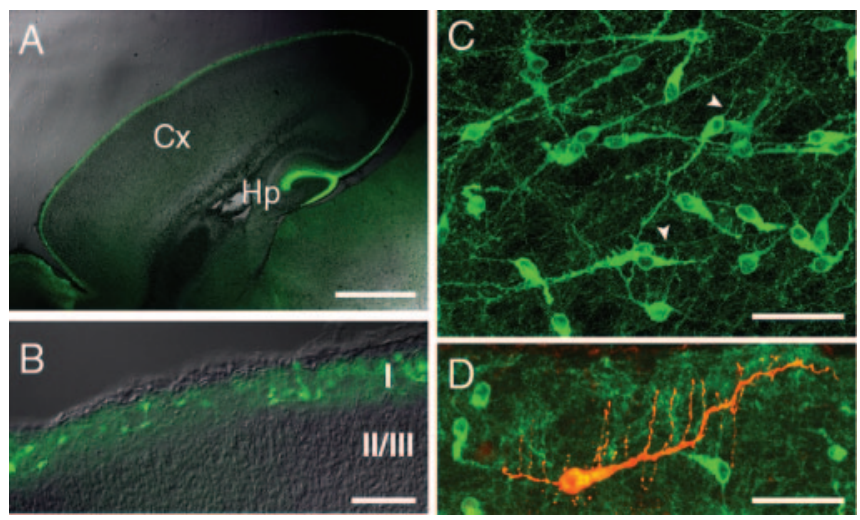

Figure 1. GFP expression at the postnatal stage of transgenic mice. A, A parasagittal section illustrating the GFP distribution in P5 transgenic mouse. Cx, Neocortex; Hp, hippocampus. Scale bar, $1 \mathrm{~mm}$. B, A magnified view of a coronal section through the somatosensory neocortex. I, Layer 1; II/III, layer 2/3. Scale bar, $100 \mu \mathrm{m}$. C, Confocal image of GFP-positive neurons with a morphology characteristic of CR cells in a tangential section of layer 1; a thin axon is marked by an arrowhead. Scale bar, $50 \mu \mathrm{m}$. D, Confocal image of a GFP-positive cell filled with biocytin and visualized with Alexa 594 -streptavidin (red), showing numerous vertical side branches from both the axon and the dendrite toward the pial surface (top). Scale bar, $50 \mu \mathrm{m}$.

(APV; $50 \mu \mathrm{M}$ ), 6-cyano-7-nitroquinoxaline-2,3-dione (CNQX; $10 \mu \mathrm{M}$ ), and tetrodotoxin (TTX; $1 \mu \mathrm{M}$ ) (all from Tocris Cookson, Bristol, UK) and octanol (1 mm; Nacalai, Kyoto, Japan). The holding potential for voltage-clamp recordings was set at $-60 \mathrm{mV}$ unless otherwise indicated. The reversal potential of $\mathrm{GABA}_{\mathrm{A}}$ receptor-mediated currents $\left(\mathrm{E}_{\mathrm{GABAA}}\right)$ in the $\mathrm{CsH}_{2} \mathrm{PO}_{4}$-based pipette solution was empirically determined to be $-38 \mathrm{mV}$ by puff application of the $\mathrm{GABA}_{\mathrm{A}}$ receptor agonist muscimol (Tocris) in the presence of APV and CNQX. A slight shift of $\mathrm{E}_{\mathrm{GABAA}}$ to a positive value compared with that calculated from the Nernst equation may be attributable to a weak permeability of phosphate ion through $\mathrm{GABA}_{\mathrm{A}}$ receptor channels (Bormann et al., 1987). Data are expressed as means \pm SEM. Excitatory effects of GABA on CR and non-CR cells were measured by calcium imaging of fura-2-loaded cortical slices as described previously (Nakahara et al., 1997); $\mathrm{GABA}_{\mathrm{A}}$ receptor responses were isolated by the application of muscimol $(100 \mu \mathrm{M})$ in the presence of $\mathrm{APV}, \mathrm{CNQX}$, and the glycine receptor antagonist strychnine.

\section{Results}

\section{GFP-expressing neurons during the postnatal period}

The mGluR2 5'-genomic sequence has the ability to direct the expression of the hIL-2R/GFP transgene in many mGluR2expressing neurons (Watanabe et al., 1998). Because mGluR2 immunoreactivity was reported to be detected in CR-like neurons in layer 1 of the adult rat cerebral cortex (Ohishi et al., 1998), we examined the expression of the hIL-2R/GFP fusion protein in the developing brain with GFP fluorescence imaging analysis. At an early postnatal day (P0, P5, and P10), conspicuous GFP fluorescence was seen in layer 1 of the neocortex, the stratum lacunosum moleculare of the hippocampus, and the molecular layer of dentate gyrus (Fig. 1A). Moderate GFP fluorescence was also seen in the olfactory bulb, the external granular layer of the cerebellum, and some cells in the striatum (data not shown). This expression pattern of GFP agreed with the distribution of reelinpositive cells at the postnatal stage (Ikeda and Terashima, 1997; Schiffmann et al., 1997). In a magnified view (Fig. 1B), GFPpositive neurons were horizontally oriented and frequently sent distinctive ascending branches that ended near the pia, as better observed with intracellular biocytin labeling (Fig. $1 D$ ). In tangential sections of the neocortex, GFP-positive neurons showed a large fusiform soma from which a single thick dendrite and a thin axon arose (Fig. 1C). Thus, GFP-positive cells exhibited the morphology characteristic of CR cells. The unique GFP expression 


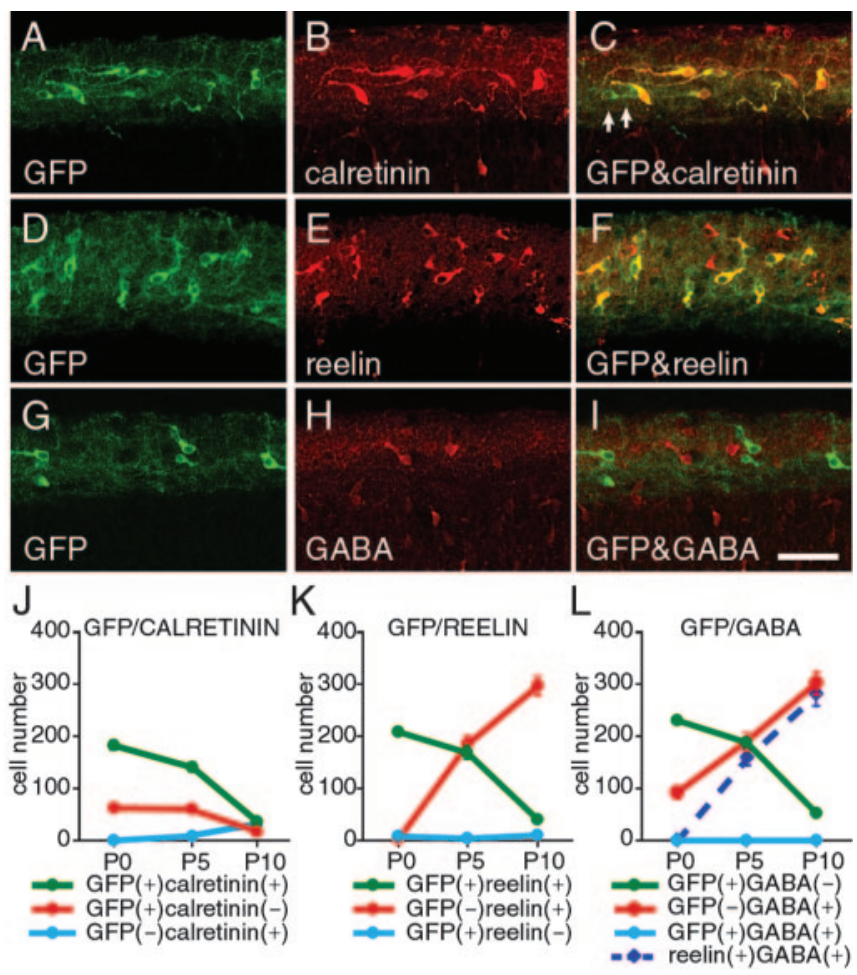

Figure 2. Characterization of the different neuronal populations in layer 1 of the somatosensory neocortex during the postnatal period. Coronal sections of the somatosensory neocortex of P5 transgenic mice were confocally visualized with GFP fluorescence in combination with immunostaining using the calretinin antibody, the reelin antibody, and the GABA antibody. $A-C$, Almost all calretinin-positive neurons were GFP-positive, but calretinin-negative neurons were also seen in the GFP-positive population, as marked by arrows. $D-F$, Virtually all GFPpositive neurons were reelin-positive, but appreciable reelin-positive/GFP-negative neurons were also detected at P5. G-I, GFP fluorescence was completely segregated from GABA immunoreactivity. Scale bar, $50 \mu \mathrm{m}$. $J-L$, The number of different cell populations as identified by GFP fluorescence and immunostaining was counted at one side of layer 1 of transgenic animals ( $n=5$ for P0 and P5 and $n=3$ for P10); the cell population was analyzed by double immunostaining with the reelin and GABA antibodies in L. Data are means \pm SEM.

profile during the postnatal period was similarly observed in an independent line (line IG16; Watanabe et al., 1998) of transgenic mice (data not shown). Unexpectedly, in situ hybridization signals of $m$ GluR2 mRNA were not high in CR cells compared with those in other brain regions (data not shown). These findings suggest that the $5^{\prime}$-genomic mGluR2 sequence we used is capable of enhancing a cell-specific expression of the GFP transgene in CR cells during development.

\section{Immunohistochemical characterization of GFP-positive neurons in layer 1}

GFP-positive neurons in layer 1 were further characterized by immunostaining at P0, P5, and P10. Although the numbers of positive neurons were different in the rostral, central, and caudal parts of the brain, a common feature was observed with respect to relative numbers and ontogeny of individual cell types. Data for the central part of the brain, which corresponds to the somatosensory neocortex, are presented in Figure 2.

GFP-positive neurons were present as a major neuronal population of layer 1 at $\mathrm{P} 0$ and progressively decreased at the later stage (Fig. $2 J-L$ ). This fate of GFP-positive neurons was consistent with that of CR cells during the postnatal period (Derer and Derer, 1990; Del Río et al., 1995). A large portion of calretininpositive neurons, a marker of CR cells (Del Río et al., 1995), were
GFP-positive at $\mathrm{P} 0$ and progressively decreased thereafter in parallel with GFP-positive neurons (Fig. $2 J$ ). A few GFP-positive/ calretinin-negative cells were also seen in layer 1 (Fig. 2A-C,J), although they showed CR cell morphology. Reelin immunoreactivity completely overlapped GFP fluorescence in layer 1 at P0 (Fig. $2 \mathrm{~K}$ ), but at P5 and P10, GFP-positive neurons accounted for approximately one-half and one-seventh of the reelin-positive population, respectively (Fig. $2 D-F, K$ ). Double-immunostaining with the reelin and GABA antibodies revealed that none of the GFPpositive neurons was GABA-immunoreactive throughout P0, P5, and P10 (Fig. 2G-I,L). Because reelin-positive neurons were GFPpositive at $\mathrm{P} 0$, they were also GABA-negative at $\mathrm{P} 0$ (Fig. $2 \mathrm{~L}$ ). At the subsequent stage, reelin-positive neurons were distinguished into two groups; reelin-positive/GFP-positive neurons were never GABA-positive, whereas reelin-positive/GFP-negative neurons were GABA-positive and became a major population of reelinpositive neurons at the later stage (Fig. $2 L$ ). This investigation indicates that the hIL-2R/GFP fusion protein is selectively expressed in $\mathrm{CR}$ cells of transgenic mice and that the reelin-positive cell population is categorized into GFP-positive/GABA-negative and GFPnegative/GABA-positive neurons at the early postnatal period.

Reelin was thought to be a representative marker of CR cells (Ogawa et al., 1995). The presence of substantial reelin-positive non-CR cells at the P5-P10 stage was striking, but consistent with the recent observations (Alcántara et al., 1998; Meyer et al., 1998). Alcántara et al. (1998) reported that reelin mRNA was completely colocalized with calretinin immunoreactivity in layer 1 at $\mathrm{P} 0$, but reelin mRNA-positive neurons substantially became calretininimmunonegative at the later stage. The reelin-positive non-CR cells were also characterized by intracellular biocytin labeling together with whole-cell recording (Fig. 3). Biocytin labeling of reelin-positive/GFP-negative cells showed that these cells were morphologically different from CR cells (Fig. 3A-C) and looked like neurogliaform cells ( 18 of 30 cells) (Jones, 1984; Hestrin and Armstrong, 1996) and cells with descending axons (8 of 30 cells) (Hestrin and Armstrong, 1996). Furthermore, in both types of cells, not only action potentials were induced by depolarizing currents in current-clamp recordings but inward currents followed by outward currents were also elicited by stepwise depolarization in voltage-clamp recordings (Fig. 3D,E). These findings indicate that the non-CR cells express reelin and possess the electrophysiological properties characteristic of neuronal cells.

\section{Spontaneous synaptic activities of layer 1 neurons}

The clear identification of GFP-positive CR cells under fluorescence microscopy in combination with IR-DIC imaging allowed us to monitor neuronal activities of CR and non-CR cells precisely in slice preparations individually and simultaneously (Fig. $4 A$ ). Whole-cell recordings were conducted in layer 1 of P2-P8 neonatal mice. The injection of depolarizing currents gave rise to action potentials in CR cells (data not shown). At the holding potential of $-60 \mathrm{mV}$, sPSCs were recorded in all CR $(n=43)$ and non-CR cells $(n=30)$ tested (Fig. $4 B, C)$. The frequency of sPSCs varied from cell to cell in both CR and non-CR cells, ranging from 0.005 to $1.02 \mathrm{~Hz}$. sPSCs in rat CR cells were reported to cease after P4 (Kilb and Luhmann, 2001). In our experiments, sPSCs of CR cells were detectable at least up to P10. This different observation may be attributable to differences in animal species, slice preparations, or recording conditions.

The sPSCs of CR cells showed a uniform current profile with a half-width of $15.1 \pm 1.0 \mathrm{msec}(n=10$ cells) (Fig. $4 B)$. In contrast, the sPSCs of non-CR cells consisted of the above current component and the more rapid current component with a half-width of 

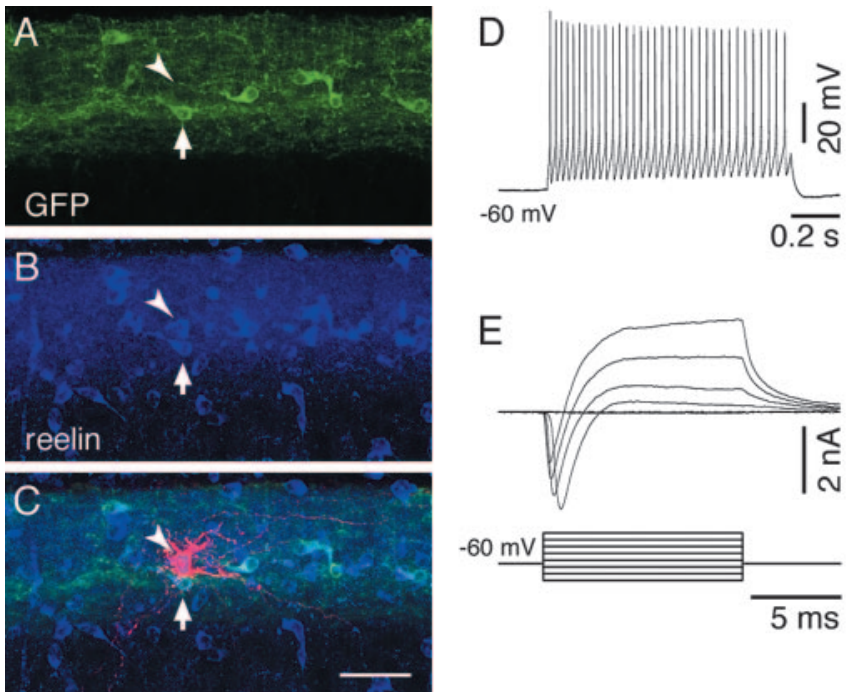

$5 \mathrm{~ms}$

Figure 3. Morphological and electrophysiological characterization of reelin-positive/GFPnegative non-CR cells. A GFP-negative cell was identified in a coronal slice at P8 by IR-DIC and GFP fluorescence and filled with biocytin. Whole-cell recording of the GFP-negative cell was then performed in current-clamp mode by delivering a depolarizing current $(D)$. Voltage-clamp recording was also conducted by holding the membrane potential at $-60 \mathrm{mV}$ and then changing the potential from -110 to $+30 \mathrm{mV}$ in a stepwise manner with a $20 \mathrm{mV}$ increment $(E)$. The reelin immunoreactivity of the electrophysiologically characterized GFP-negative cell was examined by immunostaining with reelin antibody followed by Cy5-conjugated secondary antibody $(B)$, and its morphology was characterized by Alexa Fluor 546-conjugated streptavidin (C). Confocal images of GFP fluorescence $(A)$ and reelin immunoreactivity $(B)$ and a merged view of $A$ and $B$ together with biocytin labeling $(C)$ are indicated; the reelin-positive/GFPnegative non-CR cell electrophysiologically characterized in $D$ and $E$, and its neighboring reelinpositive/GFP-positive CR cell are indicated by an arrowhead and an arrow, respectively. Scale bar, $50 \mu \mathrm{m}$

$1.5 \pm 0.1 \mathrm{msec}(n=5$ cells $)$ (Fig. $4 C)$. The sPSCs of CR cells were completely blocked by the $\mathrm{GABA}_{\mathrm{A}}$ receptor antagonist bicuculline $(20 \mu \mathrm{M} ; n=20)$ but not by the combined application of the AMPA-receptor antagonist CNQX $(10 \mu \mathrm{M})$ and the NMDAreceptor antagonist APV $(50 \mu \mathrm{M} ; n=16)$ (Fig. $4 B)$. The sPSCs of CR cells reversed at the holding potential of $-38 \mathrm{mV}(n=5$; data not shown). This value was close to the reversal potential of a $\mathrm{Cl}^{-}$ current generated by the $\mathrm{GABA}_{\mathrm{A}}$ agonist muscimol but not to that generated by glutamate $(0 \mathrm{mV})$. At the holding potential of $+40 \mathrm{mV}$, at which the $\mathrm{Mg}^{2+}$ block of NMDA receptors was relieved, the outward currents were observed and again completely abolished by bicuculline ( $n=5$; data not shown). These results indicate that synaptic inputs to $\mathrm{CR}$ cells are mediated by $\mathrm{GABA}_{\mathrm{A}}$ receptors.

The slower component of non-CR cell sPSCs at $-60 \mathrm{mV}$ was abolished by bicuculline, but the complete block of the two current components of non-CR cells required a combined application of bicuculline and CNQX $(n=5)$ (Fig. $4 C)$. Furthermore, at the holding potential of $+40 \mathrm{mV}$, the outward sPSCs resistant to bicuculline and CNQX were observed, and these currents were abolished by the additional application of APV $(n=5)$ (Fig. $4 C)$. These results indicate that synaptic inputs to non-CR cells are mediated by not only $\mathrm{GABA}_{\mathrm{A}}$ receptors but also by AMPA and NMDA receptors.

\section{Synchronous barrages of sPSCs of layer 1 neurons}

Simultaneous whole-cell recordings of a CR cell and its neighboring CR or non-CR cell showed no significant temporal correlation of sPSCs among layer 1 neurons. Because NMDA receptors
A
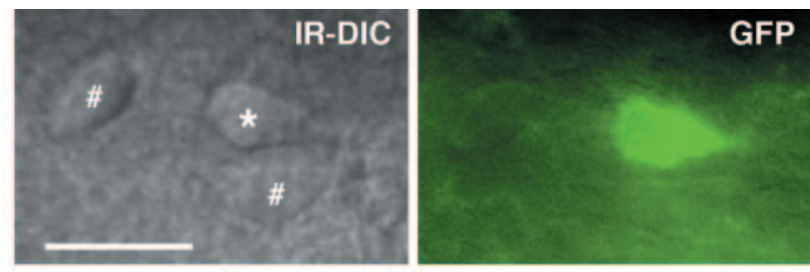

B CR control
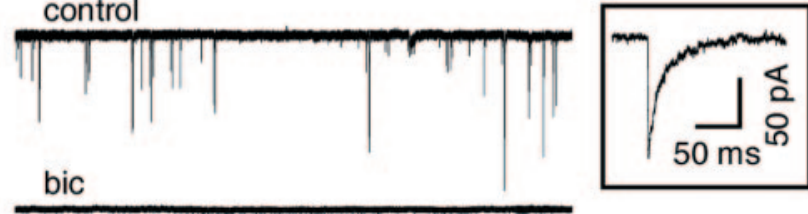

$\mathrm{APV}+\mathrm{CNQX}$

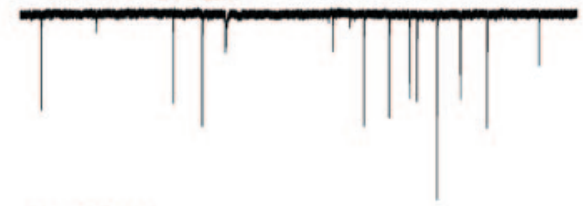

$100 \mathrm{pA}$

$20 \mathrm{~s}$

\section{C non-CR}
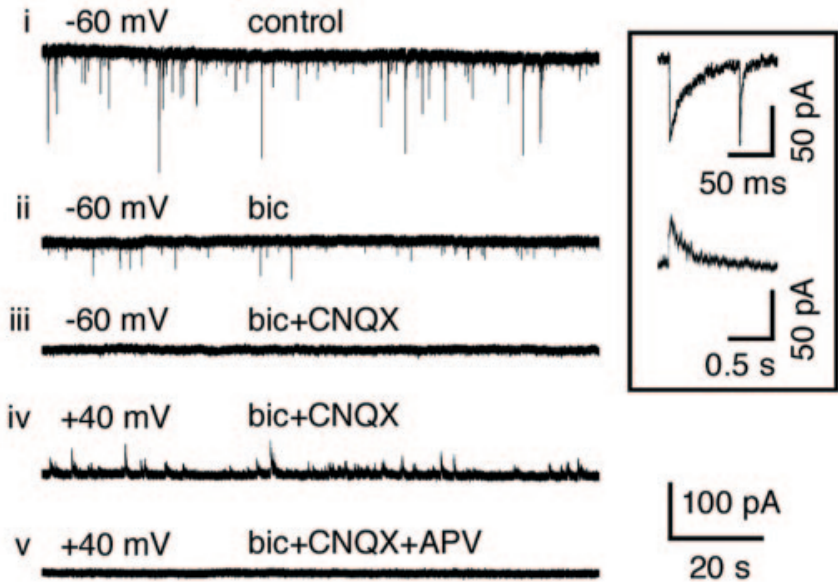

Figure 4. Whole-cell recordings of sPSCS of CR and non-CR cells. A, IR-DIC and GFP fluorescence images of a CR cell (*) and its neighboring non-CR cells (\#) of a P7 slice preparation. Scale bar, $20 \mu \mathrm{m}$. B, sPSCs recorded from a CR cell were blocked by bicuculline (bic) but not by APV plus CNQX. These SPSCs constituted a slow component as illustrated in the inset. C, sPSCs recorded from a non-CR cell at the standard holding potential ( $-60 \mathrm{mV}$ ) (i) were composed of the slow and rapid components (inset, top). The slow component was abolished by bicuculline (ii), whereas the rapid component was eliminated by the additional application of CNQX (iii). At the holding potential of $+40 \mathrm{mV}$, more slowly decaying sPSCs (inset, bottom) were observed in the presence of bicuculline and CNQX (iv) and abolished by APV (v).

are critical in evoking synchronous neuronal activity in the cortical network (Flint et al., 1997; Garaschuk et al., 2000; Quilichini et al., 2002), whole-cell recordings were conducted in an $\mathrm{Mg}^{2+}$ free extracellular solution in which the $\mathrm{Mg}^{2+}$ block of NMDA receptors was relieved. Under the $\mathrm{Mg}^{2+}$-free condition, prominent synchronous barrages of sPSCs were observed in addition to single-peaked sPSCs between the CR and non-CR cells $(n=46$ pairs; frequency, $0.87 \pm 0.11$ event $/ \mathrm{min}$; duration of each event, $2.1 \pm 0.1 \mathrm{sec}$ ) (Fig. 5A). The synchronous sPSCs bursts were observed globally not only between a pair of CR and non-CR cells but also between a pair of a CR cell and a layer $2 / 3$ pyramidal neuron ( $n=9$ pairs). The barrages of sPSCs, but not the singlepeaked sPSCs, in both types of layer 1 neurons were completely abolished by the application of TTX $(1 \mu \mathrm{M})(n=3)$. In contrast, 

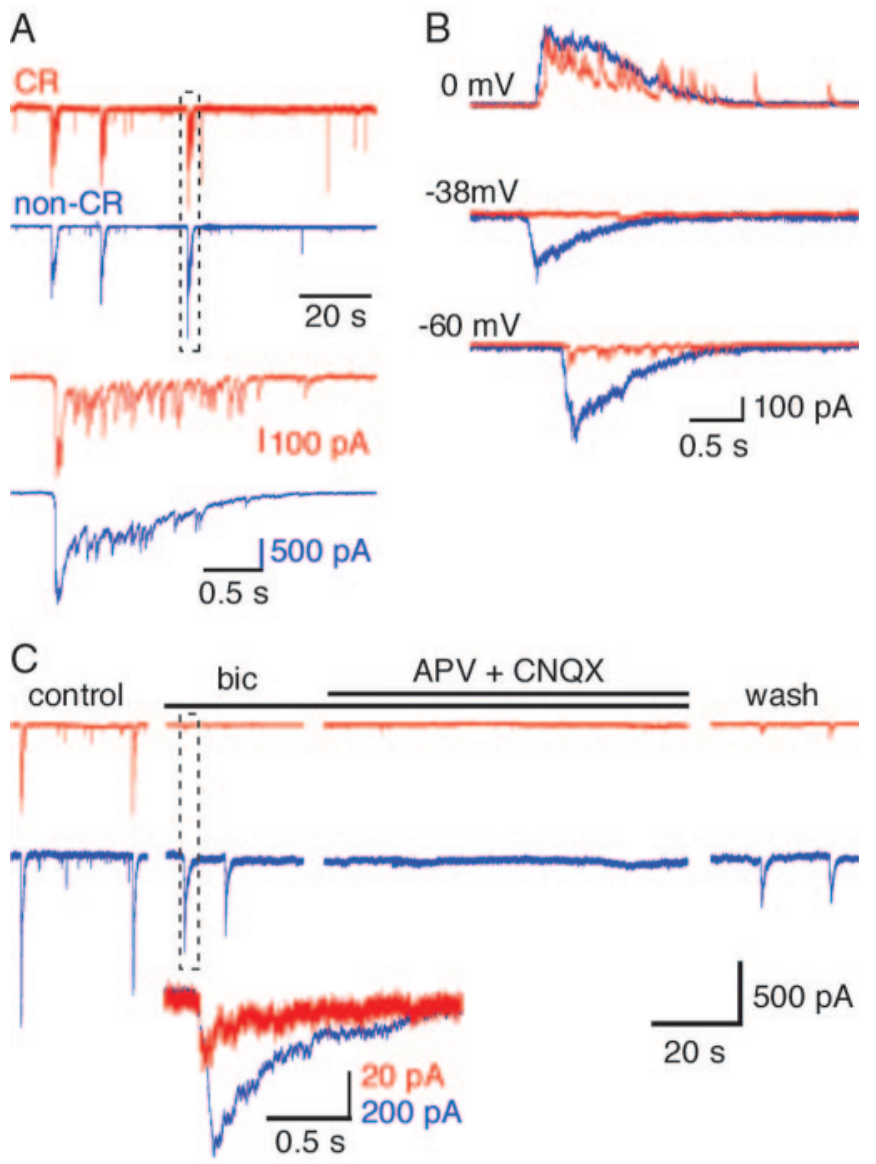

Figure 5. Simultaneous recordings of $\mathrm{CR}(\mathrm{red})$ and non-CR (blue) cells in the $\mathrm{Mg}^{2+}$-free bath solution. $A$, Synchronous, repetitive barrages of $\mathrm{SPSCs}$ occurred between a CR cell and a non-CR cell. One of the barrages (the boxed area) is expanded below. B, The barrage of sPSCs of the CR cell reversed at the holding potential of $-38 \mathrm{mV}$, whereas that of the non-CR cell was still observed at this potential. C, The barrage of sPSCs of a CR cell was abolished by bicuculline, whereas that of a non-CR cell was attenuated but still left by bicuculline and abolished by the additional application of APV and CNQX. In the bottom, currents in the boxed area are expanded to examine the bicuculline-resistant SPSCS of a CR cell. The P6, P7, and P8 slices used are indicated in $A-C$, respectively.

the gap-junction blocker octanol ( $1 \mathrm{~mm})$ had no effect on any of the sPSCs $(n=3)$. These findings indicate that the barrages of sPSCs for both CR and non-CR cells are mediated by chemical synaptic transmission rather than by electrical transmission.

In CR cells, the barrage of outward sPSCs was observed at the holding potential of $0 \mathrm{mV}$ and disappeared at the holding potential of $-38 \mathrm{mV}(n=15)$ (Fig. $5 B)$. In contrast, non-CR cells showed the burst of sPSCs at all three holding potentials of 0 , -38 , and $-60 \mathrm{mV}(n=18)$ (Fig. $5 B)$. Furthermore, the bicuculline treatment abolished the barrage of sPSCs of CR cells $(n=16)$ but left appreciable barrages of sPSCs of non-CR cells (Fig. 5C); the peak amplitude in each set of sPSCs was reduced to $26.0 \pm$ $5.2 \%$ of that in bicuculline-untreated non-CR cells $(n=9)$. Collectively, these observations suggest that the barrage of sPSCs of $\mathrm{CR}$ cells results from the activation of $\mathrm{GABA}_{\mathrm{A}}$ receptors, whereas that of non-CR cells is driven by the activation of both $\mathrm{GABA}_{\mathrm{A}}$ receptors and glutamate receptors. In addition, APV plus CNQX abolished the synchronous barrages of sPSCs in both CR and non-CR cells (Fig. 5C), most likely blocking the initiation of these events in the developing cortex (Garaschuk et al., 2000).

It has been reported that CR cells induce NMDA-receptormediated currents after electrical stimulation of layer 1 (Radni-
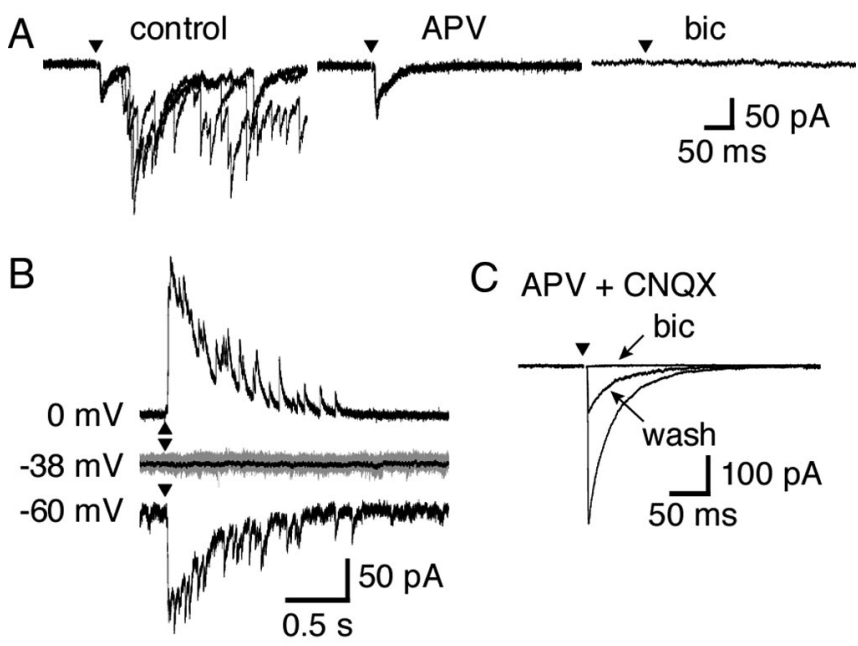

C $\mathrm{APV}+\mathrm{CNQX}$
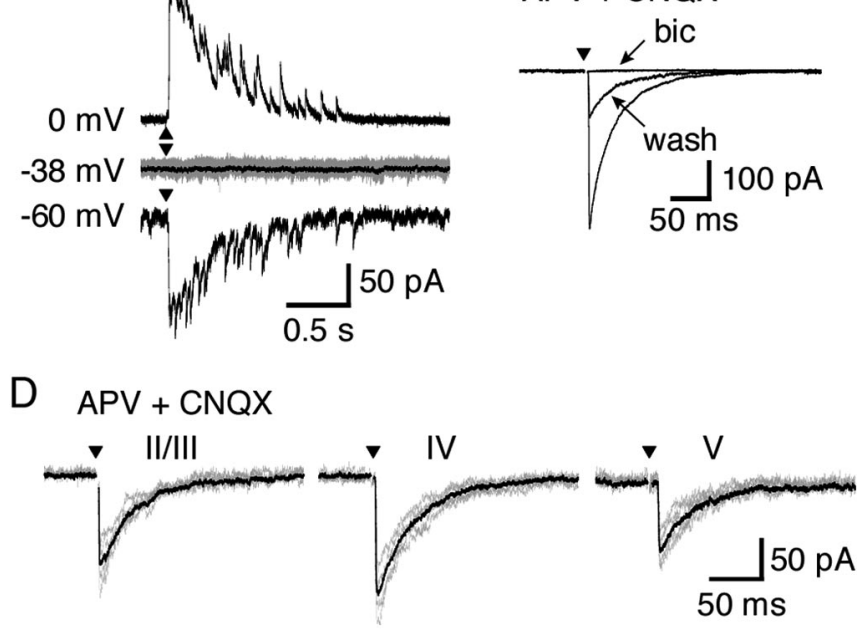

Figure 6. Whole-cell recordings of ePSCs of CR cells after electrical stimulation at developing neocortex. $A$, Seven traces recorded from a $(R$ cell after electrical stimulation (triangle) at layer 1 of a P8 slice are superimposed (left and middle) and averaged (right). B, The ePSCs after electrical stimulation at layer 1 of a $\mathrm{P} 8$ slice were recorded at three different holding potentials. Single traces at 0 and $-60 \mathrm{mV}$ are presented, and averaged and superimposed traces (10 traces) at $-38 \mathrm{mV}$ are displayed, showing no appreciable responses at $-38 \mathrm{mV}$. C, The monosynaptic ePSC (averaged 10 traces) after electrical stimulation at layer $2 / 3$ in a $\mathrm{P} 6$ slice in the presence of APV and CNQX was reversibly blocked by bicuculline. D, ePSCs were recorded from a single CR cell after serial electrical stimulation at layers $2 / 3,4$, and 5 in a P 6 slice in the presence of APV and CNQX; averaged and superimposed traces of five responses are indicated.

kow et al., 2002) or application of NMDA (Mienville and Pesold, 1999). However, in our experiments, no such bicucullineresistant sPSCs above the background levels could be detected in CR cells. Therefore, the emergence of bicuculline-resistant sPSCs of CR cells was examined at the point at which a synchronous barrage of sPSCs occurred in non-CR cells. Small-amplitude currents were observed in four of nine CR cells tested $(1.7 \pm 0.8 \%$ of bicuculline-untreated currents) (Fig. 5C), but not in the remaining five cells. This finding indicates that synaptic inputs to $\mathrm{CR}$ cells are predominantly mediated by $\mathrm{GABA}_{\mathrm{A}}$ receptors.

\section{Evoked responses of layer 1 neurons}

We next examined synaptic inputs to layer 1 neurons by delivering electrical stimulation at different neocortical layers under the $\mathrm{Mg}^{2+}$-free extracellular condition. Both $\mathrm{CR}(n=32)$ and non-CR $(n=54)$ cells showed a complex but common response pattern, regardless of stimulation sites (layers $1,2 / 3,4$, and 5) (Figs. $6 \mathrm{~A}, 7 \mathrm{~A}$ ). The initial component of ePSCs was identified as a monosynaptic response by the negligible $(<1 \mathrm{msec})$ trial-totrial variance in the latency of the current onset (Figs. 6A, 7A). This monosynaptic response was followed by a barrage of longlatency synaptic currents that were assigned as polysynaptic responses by the trial-to-trial variability in their onset and temporal pattern (Figs. 6A, 7A). In CR cells, APV completely abolished the polysynaptic components (Fig. 6A), but APV, CNQX, or both had no effect on the monosynaptic component of ePSCs $(n=5)$ (Fig. 6A,C,D). In contrast, both monosynaptic and polysynaptic 

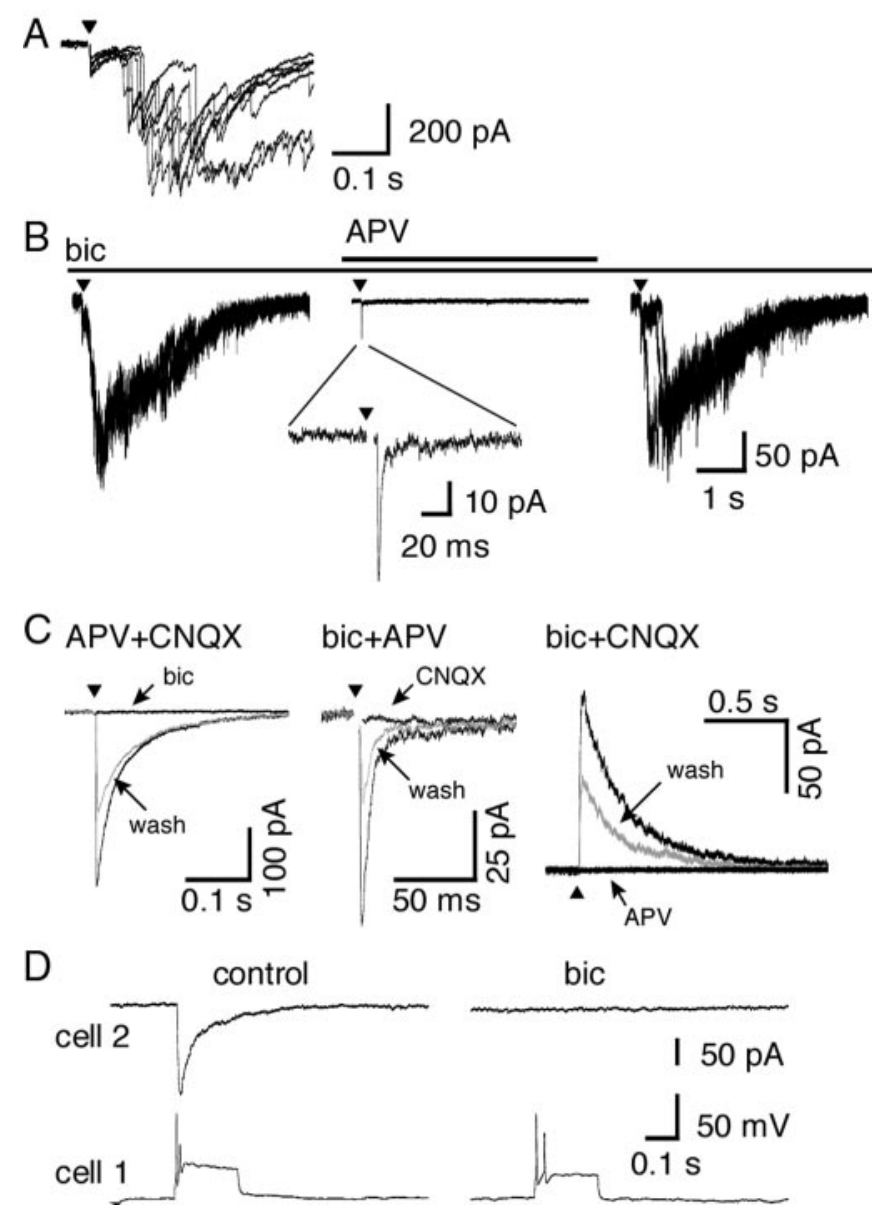

Figure 7. Whole-cell recordings of ePSCS of non-CR cells after electrical stimulation in developing neocortex. $A$, Seven traces recorded from a non-CR cell after electrical stimulation (triangle) at layer 1 of a $\mathrm{P} 6$ slice are superimposed. B, ePSCs were recorded in the presence of bicuculline after electrical stimulation at layer $2 / 3$ in a P7 slice. Both monosynaptic and polysynaptic components of non-CR cells were resistant to bicuculline (better observed in washout of APV). APV abolished the polysynaptic component but still left the very rapid monosynaptic currents. Three traces were superimposed (left and right) and averaged (middle). C, The monosynaptic ePSCs of non-CR cells after stimulation at layer 1 in a P8 slice were characterized by different combinations of antagonists. D, Paired recording between $P 9$ non- $C R$ cells. The action potential elicited by current injection into cell 1 induced ePSC in postsynaptic cell 2 , which was completely blocked by bicuculline.

components disappeared as a result of the application of bicuculline $(n=12)$ (Fig. 6A,C). Furthermore, both the monosynaptic and polysynaptic currents reversed at $-38 \mathrm{mV}(n=8)$ (Fig. $6 B)$. The results indicate that $\mathrm{GABA}_{\mathrm{A}}$ receptors play a key role in $\mathrm{CR}$ cells in receiving synaptic inputs after electrical stimuli at different layers of the neocortex.

In non-CR cells, APV effectively eliminated the polysynaptic component of ePSCs $(n=5)$ (Fig. $7 B, C)$. The important difference of ePSCs between CR and non-CR cells was that bicuculline reduced but left significant monosynaptic and polysynaptic responses in non-CR cells $(n=5)$ (Fig. $7 B)$. Thus, the monosynaptic response was examined by different combinations of bicuculline, CNQX, and APV (Fig. 7C). The monosynaptic response was detected in the presence of APV and CNQX and was completely and reversibly eliminated by the additional application of bicuculline $(n=5)$. Next, the rapidly decaying monosynaptic currents were observed in the presence of bicuculline and APV (Fig. $7 B, C$ ), which were eliminated by the additional application of CNQX $(n=5)$. Finally, bicuculline and CNQX were added in the presence of $1 \mathrm{mM} \mathrm{Mg}^{2+}$ to prevent the appearance of NMDAreceptor-dependent polysynaptic currents. The monosynaptic currents of non-CR cells were then recorded by holding the membrane potential at $+40 \mathrm{mV}$, in which $\mathrm{Mg}^{2+}$ block of NMDA receptors was relieved at the non-CR cell recorded but not at the preceding synaptic transmission. The slowly decaying monosynaptic currents were detected and reversibly abolished by APV $(n=5)$. Collectively, these results indicate that synaptic inputs to non-CR cells after electrical stimulation are mediated by $\mathrm{GABA}_{\mathrm{A}}$ receptors and AMPA and NMDA receptors.

In immature neurons, GABA acts as an excitatory transmitter, because of a high intracellular $\mathrm{Cl}^{-}$concentration maintained by an active chloride transport mechanism (Ben-Ari et al., 1989; Owens et al., 1996; Leinekugel et al., 1997; Schwartz et al., 1998; Dammerman et al., 2000; Ben-Ari, 2002; Owens and Kriegstein, 2002). We examined the effect of the $\mathrm{GABA}_{\mathrm{A}}$ receptor agonist muscimol on the intracellular $\mathrm{Ca}^{2+}$ increase in fura-2-loaded $\mathrm{CR}$ and non-CR cells at P2-P8. This examination confirmed that GABA serves as an excitatory transmitter in both types of layer 1 cells during the early postnatal period (Schwartz et al., 1998).

We next investigated the synaptic connections among CR and non-CR cells by paired recordings between layer 1 neurons. When non-CR cell 1 was recorded by eliciting action potentials at non-CR cell 2, synaptic responses were clearly observed in 5 of 20 paired non-CR cells (Fig. 7D). One of these responses was blocked by bicuculline (Fig. 7D), but other paired non-CR cells were not as stable for further characterizing their pharmacological properties. When paired recordings were conducted between a CR cell and a non-CR cell, we detected a synaptic response in 1 of $80 \mathrm{CR}$ cells and failed to see any response in 80 non-CR cells (data not shown). Synaptic transmission between CR cells is unlikely, because these cells were GABA-immunonegative and received GABAergic input. Although our findings do not exclude the synaptic input-output relation between $\mathrm{CR}$ and non-CR cells, the major synaptic inputs of layer 1 neurons are most likely derived from underlying layers of neocortex or subcortical regions.

\section{Discussion}

In this investigation, we demonstrate that the hIL-2R/GFP protein, when driven by the mGluR2 promoter, is specifically expressed in CR cells during the early postnatal period. CR cells are generated at embryonic day 10 (E10) to E11, occupy a major cell population in layer 1 , and gradually decrease after birth (Caviness, 1982; Derer and Derer, 1990; Ferrer et al., 1992; Del Río et al., 1995). GFP-positive cells with a characteristic morphology of CR cells were first detected at $\sim$ E12.5 in the marginal zone of the developing cortex (data not shown). They represented a major population of layer 1 neurons at $\mathrm{P} 0$ and then declined during the subsequent postnatal period. A minor subpopulation of CR cells, termed atypical CR cells, slightly differ in the localization and dendritic configuration (Radnikow et al., 2002). In this investigation, GFP fluorescence was seen in all cells showing CR cell morphology throughout layer 1, indicating that the hIL-2R/GFP protein is expressed in both typical and atypical CR cells. Therefore, the mGluR2 $5^{\prime}$-genomic sequence used in this study provides an intriguing tool to investigate regulatory elements that govern the fate of CR cells during development. Interestingly, GFP-positive neurons were all reelin-positive at P0 but the GFPpositive cell population decreased among reelin-positive neurons at the subsequent stages. Furthermore, GFP-positive/reelinpositive neurons never showed GABA immunoreactivity, but GFP-negative/reelin-positive neurons at the later stage were all 


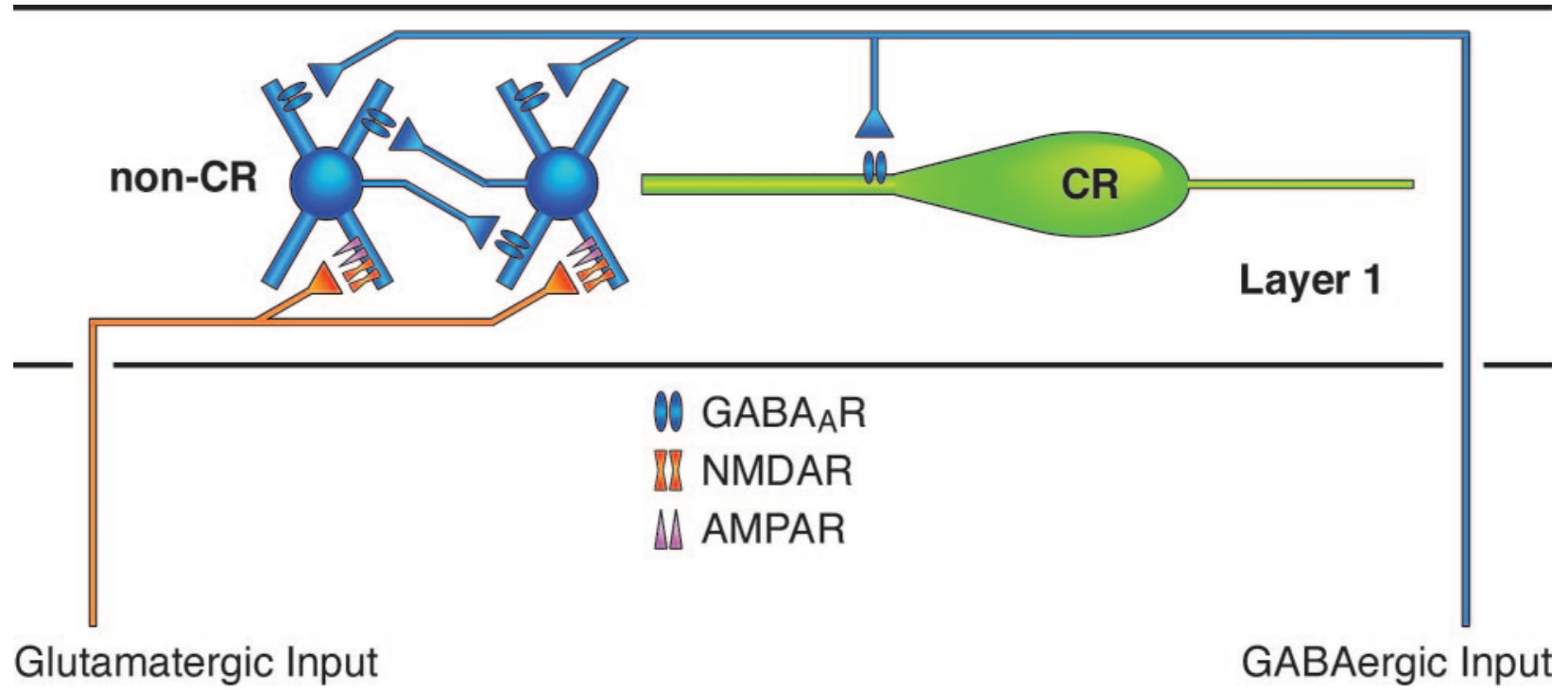

Figure 8. A network activity model of developing neocortical layer 1. CR cells receive GABAergic synaptic inputs via $G A B A_{A}$ receptors, whereas non-CR cells receive both GABAergic and glutamatergic inputs via $G_{A B A}$, NMDA, and AMPA receptors. Non-CR cells make synaptic connections with each other.

GABA-immunoreactive. These findings demonstrate that the layer 1 neuronal populations undergo dynamic developmental changes during the early postnatal period.

Whole-cell recordings of both sPSCs and ePSCs demonstrated a clear segregation of synaptic inputs between CR cells and non-CR cells in the early postnatal period (Fig. 8). Inputs to CR cells are predominantly mediated by $\mathrm{GABA}_{\mathrm{A}}$ receptors, whereas non-CR cells receive both GABAergic inputs via $\mathrm{GABA}_{\mathrm{A}}$ receptors and glutamatergic inputs via AMPA and NMDA receptors. Non-CR cells constitute a heterogeneous cell population (MarínPadilla, 1984; Hestrin and Armstrong, 1996), but they showed no difference in electrophysiological and pharmacological responses. Recently, the involvement of NMDA receptors in CR cell responses after electrical stimulation has been reported in the developing rat neocortex (Schwartz et al., 1998; Radnikow et al., 2002), but these NMDA-receptor-mediated responses were considerably smaller than $\mathrm{GABA}_{\mathrm{A}}$-receptor-mediated responses (Schwartz et al., 1998; Radnikow et al., 2002). Thus, GABA plays a predominant role in synaptic transmission to CR cells (Fig. 8). CR cells and non-CR cells are thought to transmit glutamatergic and GABAergic outputs, respectively, in the developing brain (Huntley and Jones, 1990; Del Río et al., 1992; 1995; Fonseca et al., 1995). Thus, CR and non-CR cells are distinctly segregated in both synaptic inputs and outputs (Fig. 8).

CR cells and non-CR cells elicited synchronized, repetitive barrages of sPSCs under the $\mathrm{Mg}^{2+}$-free conditions. This unique synchronous response occurred not only between CR cells and non-CR cells but also between CR cells and cortical pyramidal neurons, indicating that it reflects a large population activity in the early cortical network. The synchronized neuronal activity represents a hallmark of the developing nervous system in various brain regions (Ben-Ari et al., 1989; Yuste et al., 1992; Feller et al., 1996; Leinekugel et al., 1997; Garaschuk et al., 1998, 2000). The mechanisms underlying the synchronous oscillatory activity are distinctly different, and the mechanism of the synchronous sPSCs of layer 1 neurons seems to be in line with those reported for the network oscillation in the immature cortex and hippocampus (Garaschuk et al., 2000). The barrages of sPSCs of layer 1 cells were blocked by TTX or APV plus CNQX but per- sisted in the presence of octanol, suggesting that activation of ionotropic glutamate receptors is essential for the initiation of sPSC barrages in both CR and non-CR cells. Interestingly, bicuculline abolished and considerably attenuated the synchronized sPSCs of CR and non-CR cells, respectively. Thus, the postsynaptic $\mathrm{GABA}_{\mathrm{A}}$ receptors play an indispensable role in synchronized sPSCs of both cell types of layer 1. GABAergic fiber plexuses in layer 1 are composed of axons from intrinsic non-CR cells, those from cortical interneurons, and the projection from the thalamus (Hestrin and Armstrong, 1996; Castro-Alamancos and Connors, 1997; Marín-Padilla, 1998; Dammerman et al., 2000). Intrinsic GABAergic neurons in layer 1 may be involved in the local circuit (Martin et al., 1989). More importantly, layer 1 neurons are believed to constitute a temporary interface that receives afferent inputs and in turn sends outputs to target neurons during the early postnatal period (Mienville, 1999; Radnikow et al., 2002). The synchronous activation of two distinct types of layer 1 cells could serve to integrate input information and may have great consequences on target neurons in the developing cortex.

Numerous lines of evidence have indicated that the developmental organization of the functional neural network proceeds through several distinct mechanisms (Goodman and Shatz, 1993; Katz and Shatz, 1996). The secretion of reelin is an important cue that controls functional neocorticogenesis (Frotscher, 1998; Rice and Curran, 2001). Reelin is now revealed to be generated from both CR cells and non-CR cells, suggesting that both types of cells are involved in neocorticogenesis. The network formation also relies on spontaneous correlated neuronal activity (Goodman and Shatz, 1993; Katz and Shatz, 1996). The CR cells and non-CR cells undergo coordinated, repetitive activation that spreads throughout the developing neocortex. Furthermore, the layer 1 cell populations dynamically change during the early postnatal period. Thus, the coordinated regulation and the dynamic developmental changes of layer 1 neurons would greatly influence the activity-dependent developmental organization of the neocortex. Our transgenic mice express a fusion protein of hIL-2R and GFP. The hIL-2R can be selectively targeted for cell ablation by immunotoxin-mediated cell-targeting techniques (Watanabe et al., 1998). Future studies with selective ablation of CR cells will 
facilitate our understanding of the role of CR cells in coordinated network activity of layer 1 in the developing neocortex.

\section{References}

Aguiló A, Schwartz TH, Kumar VS, Peterlin ZA, Tsiola A, Soriano E, Yuste R (1999) Involvement of Cajal-Retzius neurons in spontaneous correlated activity of embryonic and postnatal layer 1 from wild-type and reeler mice. J Neurosci 19:10856-10868.

Alcántara S, Ruiz M, D’Arcangelo G, Ezan F, de Lecea L, Curran T, Sotelo C, Soriano E (1998) Regional and cellular patterns of reelin mRNA expression in the forebrain of the developing and adult mouse. J Neurosci 18:7779-7799.

Ben-Ari Y (2002) Excitatory actions of GABA during development: the nature of the nurture. Nat Rev Neurosci 3:728-739.

Ben-Ari Y, Cherubini E, Corradetti R, Gaiarsa JL (1989) Giant synaptic potentials in immature rat CA3 hippocampal neurones. J Physiol (Lond) 416:303-325.

Bormann J, Hamill OP, Sakmann B (1987) Mechanism of anion permeation through channels gated by glycine and $\gamma$-aminobutyric acid in mouse cultured spinal neurones. J Physiol (Lond) 385:243-286.

Castro-Alamancos MA, Connors BW (1997) Thalamocortical synapses. Prog Neurobiol 51:581-606.

Caviness VSJ (1982) Neocortical histogenesis in normal and reeler mice: a developmental study based upon $\left[{ }^{3} \mathrm{H}\right]$ thymidine autoradiography. Brain Res 256:293-302.

Caviness VSJ, Sidman RL (1973) Time of origin of corresponding cell classes in the cerebral cortex of normal and reeler mutant mice: an autoradiographic analysis. J Comp Neurol 148:141-151.

D’Arcangelo G, Miao GG, Chen SC, Soares HD, Morgan JI, Curran T (1995) A protein related to extracellular matrix proteins deleted in the mouse mutant reeler. Nature 374:719-723.

Dammerman RS, Flint AC, Noctor S, Kriegstein AR (2000) An excitatory GABAergic plexus in developing neocortical layer 1. J Neurophysiol 84:428-434.

Del Río JA, Soriano E, Ferrer I (1992) Development of GABAimmunoreactivity in the neocortex of the mouse. J Comp Neurol 326:501-526

Del Río JA, Martínez A, Fonseca M, Auladell C, Soriano E (1995) Glutamate-like immunoreactivity and fate of Cajal-Retzius cells in the murine cortex as identified with calretinin antibody. Cereb Cortex 5:13-21.

Derer P, Derer M (1990) Cajal-Retzius cell ontogenesis and death in mouse brain visualized with horseradish peroxidase and electron microscopy. Neuroscience 36:839-856.

Feller MB, Wellis DP, Stellwagen D, Werblin FS, Shatz CJ (1996) Requirement for cholinergic synaptic transmission in the propagation of spontaneous retinal waves. Science 272:1182-1187.

Ferrer I, Soriano E, Del Río JA, Alcántara S, Auladell C (1992) Cell death and removal in the cerebral cortex during development. Prog Neurobiol 39:1-43.

Flint AC, Maisch US, Kriegstein AR (1997) Postnatal development of low $\left[\mathrm{Mg}^{2+}\right]$ oscillations in neocortex. J Neurophysiol 78:1990-1996.

Fonseca M, Del Río JA, Martínez A, Gómez S, Soriano E (1995) Development of calretinin immunoreactivity in the neocortex of the rat. J Comp Neurol 361:177-192.

Frotscher M (1998) Cajal-Retzius cells, Reelin, and the formation of layers. Curr Opin Neurobiol 8:570-575.

Garaschuk O, Hanse E, Konnerth A (1998) Developmental profile and synaptic origin of early network oscillations in the CA1 region of rat neonatal hippocampus. J Physiol (Lond) 507:219-236.

Garaschuk O, Linn J, Eilers J, Konnerth A (2000) Large-scale oscillatory calcium waves in the immature cortex. Nat Neurosci 3:452-459.

Goodman CS, Shatz CJ (1993) Developmental mechanisms that generate precise patterns of neuronal connectivity. Cell 72:77-98.

Hestrin S, Armstrong WE (1996) Morphology and physiology of cortical neurons in layer I. J Neurosci 16:5290-5300.

Huntley GW, Jones EG (1990) Cajal-Retzius neurons in developing monkey neocortex show immunoreactivity for calcium binding proteins. J Neurocytol 19:200-212.

Ikeda Y, Terashima T (1997) Expression of reelin, the gene responsible for the reeler mutation, in embryonic development and adulthood in the mouse. Dev Dyn 210:157-172.

Jones EG (1984) Neurogliaform or spiderweb cells. In: Cerebral cortex (Peters A, Jones EG, ed), pp 409-418. New York: Plenum.

Katz LC, Shatz CJ (1996) Synaptic activity and the construction of cortical circuits. Science 274:1133-1138.

Kilb W, Luhmann HJ (2001) Spontaneous GABAergic postsynaptic currents in Cajal-Retzius cells in neonatal rat cerebral cortex. Eur J Neurosci 13:1387-1390.

Leinekugel X, Medina I, Khalilov I, Ben-Ari Y, Khazipov R (1997) $\mathrm{Ca}^{2+}$ oscillations mediated by the synergistic excitatory actions of $\mathrm{GABA}_{\mathrm{A}}$ and NMDA receptors in the neonatal hippocampus. Neuron 18:243-255.

Marín-Padilla M (1984) Neurons of layer I: a developmental analysis. In: Cerebral cortex (Peters A, Jones EG, ed), pp 447-478. New York: Plenum.

Marín-Padilla M (1998) Cajal-Retzius cells and the development of the neocortex. Trends Neurosci 21:64-71.

Martin KA, Friedlander MJ, Alones V (1989) Physiological, morphological, and cytochemical characteristics of a layer 1 neuron in cat striate cortex. J Comp Neurol 282:404-414.

Meyer G, Soria JM, Martínez-Galán JR, Martín-Clemente B, Fairén A (1998) Different origins and developmental histories of transient neurons in the marginal zone of the fetal and neonatal rat cortex. J Comp Neurol 397:493-518.

Meyer G, Goffinet AM, Fairén A (1999) What is a Cajal-Retzius cell? A reassessment of a classical cell type based on recent observations in the developing neocortex. Cereb Cortex 9:765-775.

Mienville JM (1999) Cajal-Retzius cell physiology: just in time to bridge the 20th century. Cereb Cortex 9:776-782.

Mienville JM, Pesold C (1999) Low resting potential and postnatal upregulation of NMDA receptors may cause Cajal-Retzius cell death. J Neurosci 19:1636-1646.

Nakahara K, Okada M, Nakanishi S (1997) The metabotropic glutamate receptor mGluR5 induces calcium oscillations in cultured astrocytes via protein kinase C phosphorylation. J Neurochem 69:1467-1475.

Ogawa M, Miyata T, Nakajima K, Yagyu K, Seike M, Ikenaka K, Yamamoto H, Mikoshiba K (1995) The reeler gene-associated antigen on CajalRetzius neurons is a crucial molecule for laminar organization of cortical neurons. Neuron 14:899-912.

Ohishi H, Neki A, Mizuno N (1998) Distribution of a metabotropic glutamate receptor, mGluR2, in the central nervous system of the rat and mouse: an immunohistochemical study with a monoclonal antibody. Neurosci Res 30:65-82.

Owens DF, Kriegstein AR (2002) Is there more to GABA than synaptic inhibition? Nat Rev Neurosci 3:715-727.

Owens DF, Boyce LH, Davis MB, Kriegstein AR (1996) Excitatory GABA responses in embryonic and neonatal cortical slices demonstrated by gramicidin perforated-patch recordings and calcium imaging. J Neurosci 16:6414-6423.

Quilichini PP, Diabira D, Chiron C, Ben-Ari Y, Gozlan H (2002) Persistent epileptiform activity induced by low $\mathrm{Mg}^{2+}$ in intact immature brain structures. Eur J Neurosci 16:850-860.

Radnikow G, Feldmeyer D, Lübke J (2002) Axonal projection, input and output synapses, and synaptic physiology of Cajal-Retzius cells in the developing rat neocortex. J Neurosci 22:6908-6919.

Rice DS, Curran T (2001) Role of the reelin signaling pathway in central nervous system development. Annu Rev Neurosci 24:1005-1039.

Schiffmann SN, Bernier B, Goffinet AM (1997) Reelin mRNA expression during mouse brain development. Eur J Neurosci 9:1055-1071.

Schwartz TH, Rabinowitz D, Unni V, Kumar VS, Smetters DK, Tsiola A, Yuste R (1998) Networks of coactive neurons in developing layer 1. Neuron 20:541-552.

Watanabe D, Inokawa H, Hashimoto K, Suzuki N, Kano M, Shigemoto R, Hirano T, Toyama K, Kaneko S, Yokoi M, Moriyoshi K, Suzuki M, Kobayashi K, Nagatsu T, Kreitman RJ, Pastan I, Nakanishi S (1998) Ablation of cerebellar Golgi cells disrupts synaptic integration involving GABA inhibition and NMDA receptor activation in motor coordination. Cell 95:17-27.

Yuste R, Peinado A, Katz LC (1992) Neuronal domains in developing neocortex. Science 257:665-669. 